\title{
SCUTELLAR BRISTLE COMPONENTS AND CANALISATION IN DROSOPHILA MELANOGASTER
}

\author{
W. R. SCOWCROFT \\ Division of Plant Industry, CSIRO, Canberra, A.C.T., Australia
}

Received 22.v.72

\begin{abstract}
Summary
Selection was applied to anterior and posterior scutellar bristles separately and jointly in two populations, one of which straddled the $3 / 4$ bristle threshold and the other the $4 / 5$ bristle threshold. The object was to define the thresholds of the normally canalised 4 bristle phenotype in terms of the component anterior and posterior bristles. Changes in total bristle number (anteriors plus posteriors) at the $3 / 4$ threshold is a function of addition or loss of bristles at the posterior site, whereas changes at the $4 / 5$ threshold exclusively involve anterior bristles. It is concluded that the component anterior and posterior bristles are essentially independent.
\end{abstract}

\section{INTRODUCTION}

The ease of evaluating and comparing the scutellar bristle phenotype of Drosophila melanogaster has established this character as a model for studying the relationship between developmentally controlled processes and quantitative variability. The normally canalised number of 4 bristles, two each at the anterior and posterior regions of the scutellum (fig. 1), can be readily disturbed by selection (Payne, 1918; Sismanidis, 1942; Rendel, 1959; Latter, 1964; Fraser et al., 1965; Scowcroft, 1966), by major gene substitutions (Dubinin, 1933; Lindsley and Grell, 1967; Scowcroft et al., 1968; Miller and Fraser, 1968) or by temperature (Child, 1935; Pennycuick and Fraser, 1964; Fraser et al., 1968; Gibson, 1969).

The model proposed by Rendel $(1959,1962)$ for the control of scutellar bristle development postulates that a population of individuals has an observed mean phenotypic value which is a continuous function of a single developmental variable. The normal level of this variable is subtended by two thresholds within which the number of scutellar bristles is constant at 4. Deviations either side of these thresholds lead to an increase or decrease in bristle number respectively. Rendel's model assumed that total scutellar bristle number is the primary character under control of the single developmental variable. Robertson (1965) argued that the formation of 4 bristles may not be a sequential or cumulative process and suggested that total scutellar bristle number is a function of developmental events at the individual sites which may be independent in any given individual.

By varying the dose of a series of scute alleles, Scowcroft et al. (1968) found that a single developmental scale does not adequately describe the phenomenon of canalisation of total scutellar bristle number. The posterior bristles were more strongly canalised than the anterior ones and the specification of the $3 / 4$ total bristle threshold was a function of posterior bristle number while the $4 / 5$ bristle threshold depended almost exclusively on the relative number of anterior bristles. 
Negative correlations between anterior and posterior bristles have been demonstrated in both scute populations selected for canalisation at 2 bristles (Rendel, 1965) and in wild-type populations selected to a limit of 8-10 bristles (Latter, 1970). In contrast, Latter and Scowcroft (1970) showed that at the normal level of 4 bristles the genetic correlation between anterior and posterior bristles was non-negative (i.e. zero or positive) and that posterior scutellars are more highly canalised than anteriors. Latter and Scowcroft (1970) concluded that a threshold model based on a single underlying variable is inadequate and that total bristle number must be treated as the sum of separate components. The following paper evaluates the genetic relationship between anterior and posterior bristles by studying the response to selection in two populations which straddle the critical $3 / 4$ and $4 / 5$ bristle thresholds. Selection has been practised on both anterior and posterior bristles separately and jointly.

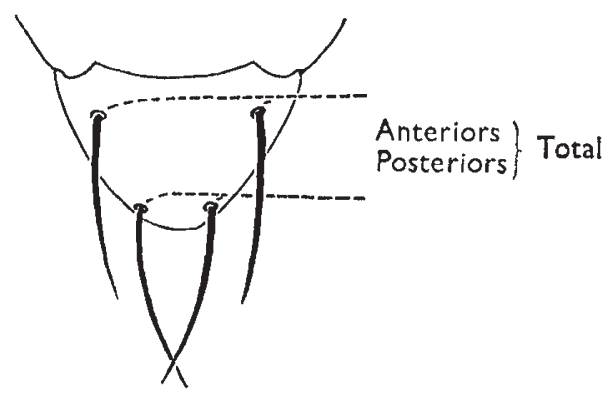

FIG. 1.-Standard wild type pattern for the location of scutellar bristles in Drosophila melanogaster.

\section{Materials AND MEthods}

The two populations $60 \mathrm{D} 3 / 4$ and $60 \mathrm{D} 4 / 5$ used in this study have been described in detail by Scowcroft and Latter (1971) where they were used to demonstrate the existence of decanalising genes. The population that straddles the $3 / 4$ threshold $(60 \mathrm{D} 3 / 4)$ and that which straddles the $4 / 5$ threshold (60D4/5) were produced by recombinational substitution of the mild scute allele, $s c^{60 d 19}$ (originally obtained from M. M. Green), into the Canberra base population and into line $\mathrm{SH}$, which was derived from the Canberra stock by selection (Latter, 1970) respectively. The bristle terminology is as for the standard wild type pattern (fig. 1). The bristle distributions and means are shown in fig. 2 and table 1 . There has been a change in bristle mean from 3.29 (Scowcroft and Latter, 1971) to 3.69 (table 1), but for the current purpose this is not considered to be important. The data for each population is treated separately as far as probit transformation is concerned. The probit transformation is warranted because of the markedly non-normal distribution of some of the bristle classes, particularly $60 \mathrm{D} 3 / 4$. Unless otherwise stated, the probit mean for total bristle number (anterior + posterior scutellar bristles) in the 60D3/4 population is relative to the $3 / 4$ threshold with an assigned probit value of 5.0 , while for the $60 \mathrm{D} 4 / 5$ population the appropriate threshold is $4 / 5$. Anterior and posterior bristle probit means for both populations are relative to the $2 / 3$ and $1 / 2$ bristle thresholds. These thresholds were chosen to minimise the standard errors of the means. 

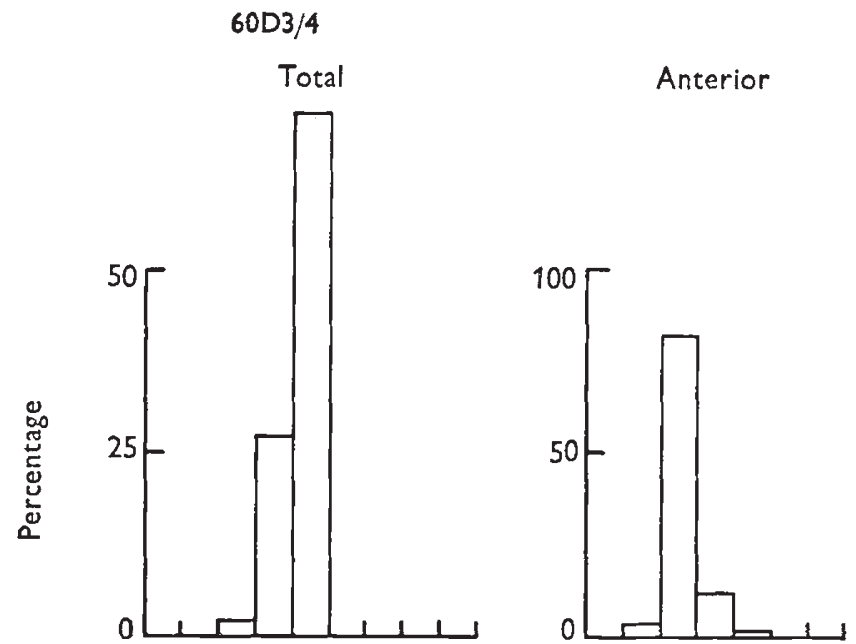

Posterior
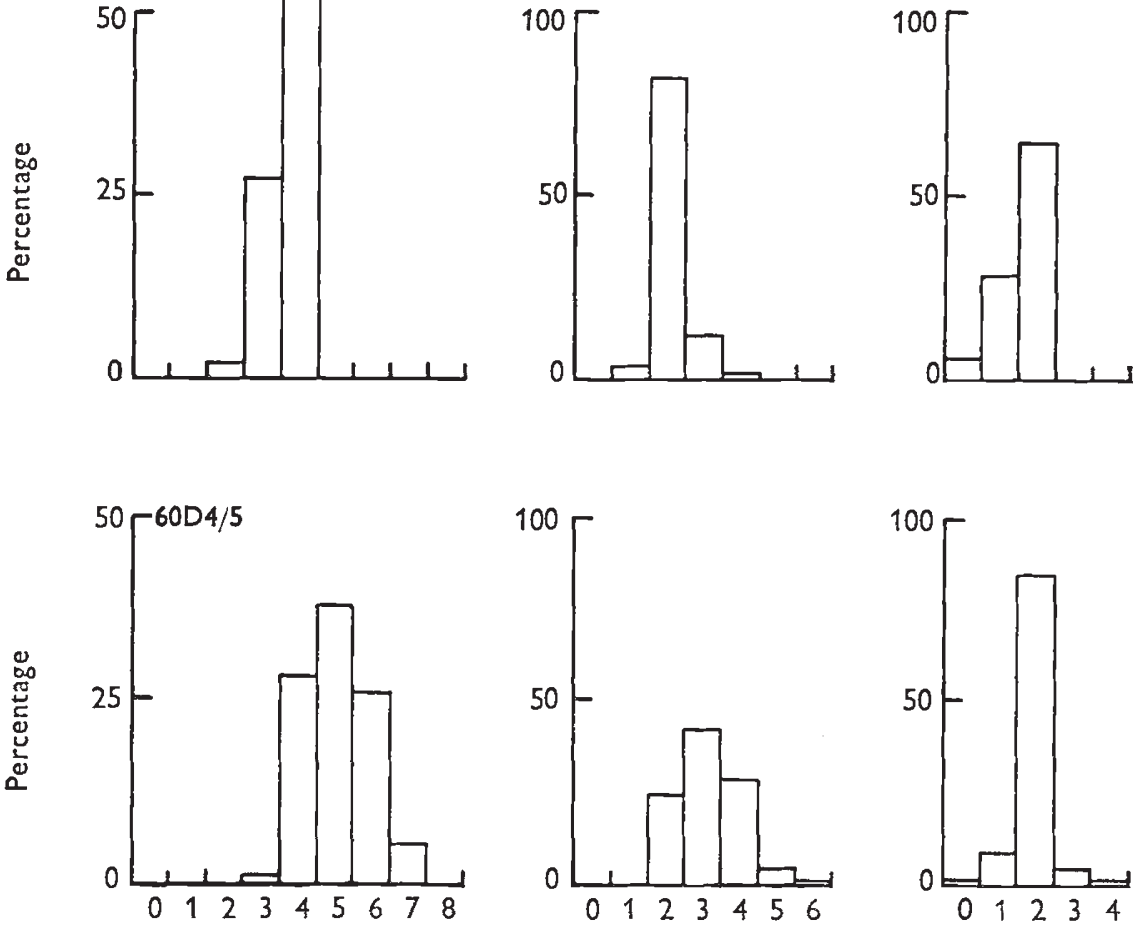

\section{Bristle class}

FIG. 2.-Frequency distributions for total, anterior and posterior scutellar bristle number for the $60 \mathrm{D} 3 / 4$ and $60 \mathrm{D} 4 / 5$ populations.

TABLE 1

Bristle means and probit means for the 60D3/4 and 60D4/5 base populations

\begin{tabular}{|c|c|c|c|c|}
\hline & \multicolumn{2}{|c|}{$60 \mathrm{D} 3 / 4$} & \multicolumn{2}{|c|}{$60 \mathrm{D} 4 / 5$} \\
\hline & $\begin{array}{l}\text { Bristle } \\
\text { mean }\end{array}$ & $\begin{array}{l}\text { Probit } \\
\text { mean* }\end{array}$ & $\begin{array}{l}\text { Bristle } \\
\text { mean }\end{array}$ & $\begin{array}{l}\text { Probit } \\
\text { mean }\end{array}$ \\
\hline $\begin{array}{l}\text { Total scutellar number } \\
\text { Anterior } \\
\text { Posterior }\end{array}$ & $\begin{array}{l}3.69 \pm 0.02 \\
2 \cdot 11 \pm 0.02 \\
1.58 \pm 0.02\end{array}$ & $\begin{array}{l}5.54 \pm 0.05 \\
3.91 \pm 0.06 \\
5.37 \pm 0.05\end{array}$ & $\begin{array}{l}5.08 \pm 0.02 \\
3 \cdot 13 \pm 0.02 \\
1.95 \pm 0.01\end{array}$ & $\begin{array}{l}5.53 \pm 0.03 \\
5.68 \pm 0.03 \\
6.29 \pm 0.04\end{array}$ \\
\hline
\end{tabular}

* See text for discussion of the appropriate threshold used to determine probit means.

From each of the two base populations a number of independent selection lines were established. In each line selection was for a given bristle type (total, anterior or posterior scutellars) and either for an increase or a decrease in the metric such that six directional selection régimes plus a 
control existed for both the 60D3/4 and 60D4/5 populations. Each selection régime was done in duplicate.

In each generation usually 100 females were scored for both anterior and posterior scutellars and selection was applied either to anterior or posterior bristles, to provide 10 selected females along with 10 random males as parents of the next generation. Where the number of females that satisfied the selection criteria was more or less than 10 , individuals were eliminated from the selected set or added at random from those previously scored. The control population was scored each generation and propagated with 10 random females and males. Parents were removed after 9 days. Selection was continued for 14 generations in the $60 \mathrm{D} 3 / 4$ populations and for 10 generations in 60D4/5. The populations were raised in half-pint cream jars on a wheatmeal-treacle-yeast fortified media at $23^{\circ} \pm 1^{\circ} \mathrm{C}$.

\section{Results}

In this study it should be emphasised that the qualitative aspects of the selection response are of prime concern. The object was to determine the change in anterior and posterior bristle components and their interrelationship with one another in determining the change in total bristle number (anteriors + posteriors) brought about by selection. The quantitative aspects of the response are important only in so far as they allow the establishment of significant effects.

The presentation and discussion of each individual selection line is not warranted. The comparative response of mean bristle number and mean probit score for the last three generations of selection are presented in tables 2 and 3 for the $60 \mathrm{D} 3 / 4$ and $60 \mathrm{D} 4 / 5$ populations respectively. To reduce the results of selection to a comprehensible form the following measures were adopted.

The response in probit value per generation was averaged for the two replicate selection lines for each régime. Secondly, the response was computed in terms of the difference between the average of the high and of the low selection lines for the respective bristle types. This latter expedient was essential since the bristle probit scores of the control lines showed a consistent change during the course of the experiment. By comparing table 1 with the control lines of table 2 it can be seen that mean probit score for total bristle and posterior bristle number for $60 \mathrm{D} 3 / 4$ decreased. A similar comparison with table 3 showed that probit values for all bristle types increased during the course of the experiment.

To establish the significance or otherwise of response to divergent selection each particular response pattern was subjected to a regression analysis. The regression coefficients along with the statistical significance of the divergence is presented in table 4 for $60 \mathrm{D} 3 / 4$ and table 6 for $60 \mathrm{D} 4 / 5$. The association of changes in total bristles with both anterior and posterior bristles and of these latter two with each other are quantified in table 5 for $60 \mathrm{D} 3 / 4$ and table 7 for $60 \mathrm{D} 4 / 5$ in terms of correlation coefficients.

\section{(A) 60D3/4 population \\ (i) Total bristle selection}

It can be seen from fig. $3 a$ that total bristle number responded to divergent selection. This response had a significant regression coefficient of 
TABLE 2

Mean bristle number and probit score (average of final three generations of selection) for total, anterior and posterior scutellar bristles for the different selection régimes for the 60D3/4 population

\section{Selection \\ régime}

Total bristles

High 1

High 2

Low 1

Low 2

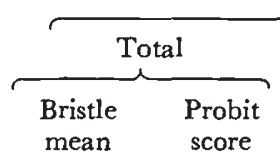

$\begin{array}{ll}3 \cdot 6 & 5 \cdot 6 \\ 3 \cdot 9 & 6 \cdot 2 \\ 3 \cdot 5 & 5 \cdot 2 \\ 3 \cdot 0 & 4 \cdot 5\end{array}$

Bristle type

\section{Anterior bristles}

$\begin{array}{lllllll}\text { High 1 } & 3 \cdot 1 & 4.5 & 2 \cdot 4 & 4 \cdot 7 & 0.7 & 3.9 \\ \text { High 2 } & 3.5 & 5 \cdot 2 & 2 \cdot 9 & 5 \cdot 5 & 0 \cdot 6 & 3.8 \\ \text { Low 1 } & 3.5 & 5 \cdot 2 & 1.9 & 3.6 & 1 \cdot 6 & 5 \cdot 4 \\ \text { Low 2 } & 3.8 & 6.0 & 2 \cdot 1 & 3.9 & 1.7 & 5.6\end{array}$

\section{Posterior bristles}

$\begin{array}{lllllll}\text { High 1 } & 3 \cdot 9 & 6 \cdot 2 & 2 \cdot 2 & 4 \cdot 0 & 1 \cdot 7 & 5 \cdot 6 \\ \text { High 2 } & 3 \cdot 8 & 6 \cdot 3 & 2 \cdot 1 & 3 \cdot 7 & 1 \cdot 7 & 5 \cdot 9 \\ \text { Low 1 } & 3 \cdot 2 & 4 \cdot 7 & 2 \cdot 4 & 4 \cdot 6 & 0 \cdot 8 & 4 \cdot 0 \\ \text { Low 2 } & 3 \cdot 1 & 4 \cdot 6 & 2 \cdot 0 & 3 \cdot 7 & 1 \cdot 1 & 4 \cdot 6 \\ \text { Control } & 3 \cdot 3 & 4 \cdot 8 & 2 \cdot 2 & 3 \cdot 9 & & \\ & & & & & & \end{array}$

TABLE 3

Mean bristle number and probit score (average of final three generations of selection) for total, anterior and posterior scutellar bristles for the different selection régimes for the 60D4/5 population

\section{Selection régime}

Total bristles

High 1

High 2

Low 1

Low 2

Anterior bristles

\section{High 1}

High 2

Low 1

Low 2

Posterior bristles

High 1
High 2
Low 1

Low 2

Control

$\overbrace{\begin{array}{c}\text { Bristle } \\ \text { mean }\end{array}}^{\text {Total }} \begin{gathered}\begin{array}{c}\text { Probit } \\ \text { score }\end{array} \\ \text { Tot }\end{gathered}$

$\begin{array}{ll}5 \cdot 5 & 6 \cdot 2 \\ 5 \cdot 7 & 6 \cdot 3 \\ 4 \cdot 7 & 5 \cdot 1 \\ 5 \cdot 1 & 5 \cdot 5\end{array}$

$\begin{array}{ll}5 \cdot 2 & 5 \cdot 7 \\ 5 \cdot 3 & 5 \cdot 7 \\ 4 \cdot 6 & 4 \cdot 9 \\ 5 \cdot 0 & 5 \cdot 4\end{array}$

Bristle type

$\overbrace{\begin{array}{c}\text { Bristle } \\ \text { mean }\end{array} \quad \begin{array}{c}\text { Probit } \\ \text { score }\end{array}}^{\text {Anterior }} \overbrace{\begin{array}{c}\text { Bristle } \\ \text { mean }\end{array}}^{\text {Posterior }}$

$\begin{array}{llll}3 \cdot 5 & 6 \cdot 2 & 2 \cdot 0 & 6 \cdot 9 \\ 3 \cdot 6 & 6 \cdot 3 & 2 \cdot 0 & 6 \cdot 8 \\ 2 \cdot 7 & 5 \cdot 2 & 2 \cdot 0 & 6 \cdot 5 \\ 3 \cdot 1 & 5 \cdot 7 & 2 \cdot 0 & 6 \cdot 5\end{array}$

2



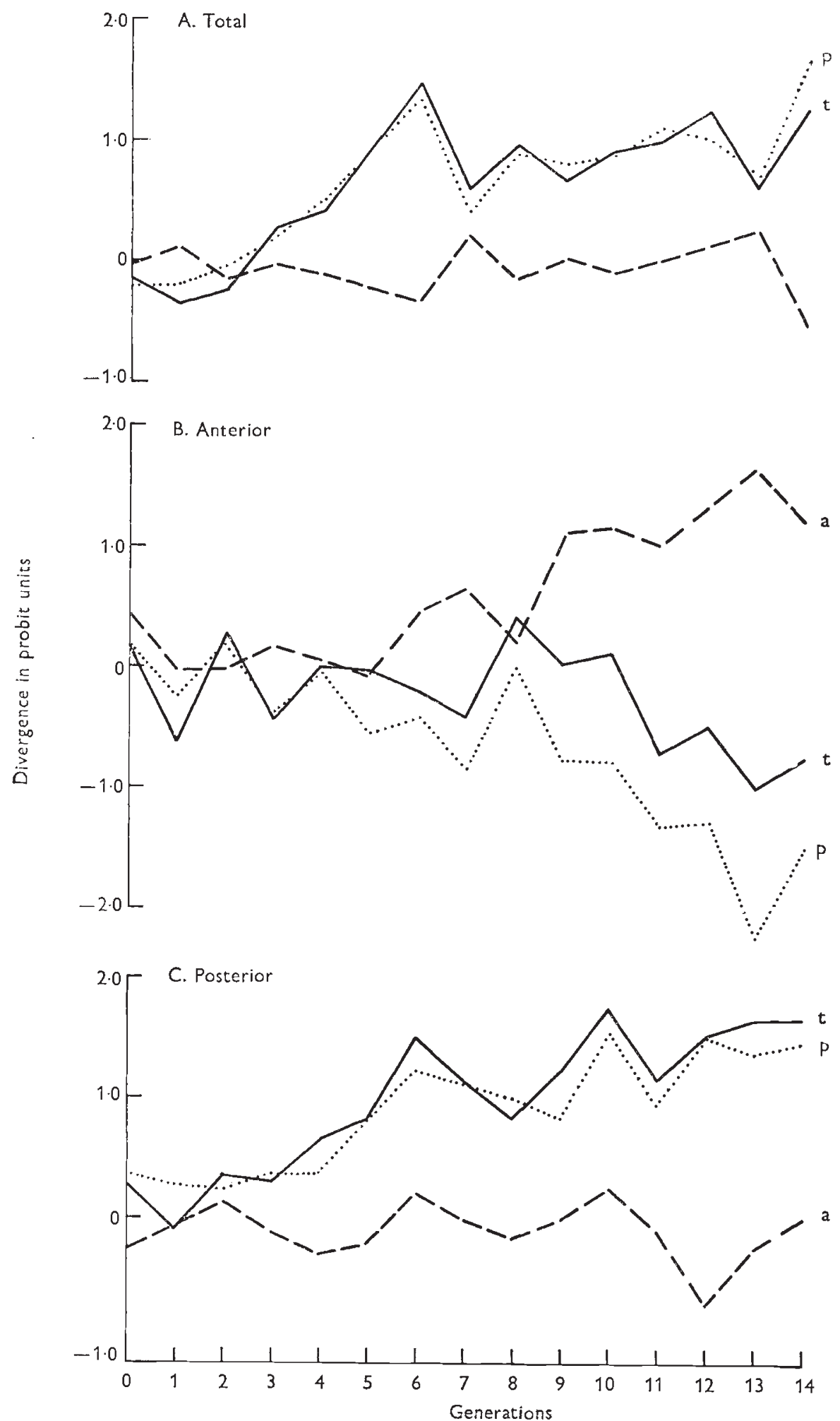

Fig. 3.--The divergence of total scutellar bristle number $(t)(-)$ anterior bristles $(a)$ $(--)$ and posterior bristles $(p)(\ldots)$ in probit units resulting from selection for directional changes in A, total bristle number; $\mathrm{B}$, anterior bristles; and $\mathrm{C}$, posterior bristles for the 60D3/4 population. 
TABLE 4

Regression coefficients for the response of total, anterior and posterior bristle numbers under diverging selection régimes for total bristles, anterior or posterior bristles respectively in the 60D3/4 population

Bristle component

\begin{tabular}{lccc} 
Selection régime & $\overbrace{\text { Total }}$ & Anterior & Posterior \\
Total scutellar bristles & $0.09 * * *$ & -0.02 & $0.10 * *$ \\
Anterior bristles & -0.05 & $0.13 * * *$ & $-0.13 *$ \\
Posterior bristles & $0.12 * * *$ & -0.02 & $0.09 * * *$ \\
\multicolumn{2}{c}{$\mathrm{P}<0.05 ; * * \mathrm{P}<0.01 ; * * * \mathrm{P}<0.001}$. &
\end{tabular}

TABLE 5

Correlation coefficients for the association of change in total bristle score with change in anteriors and posteriors and of the latter two with each other for the three different selection regimes in the 60D3/4 population

\begin{tabular}{lccl} 
& \multicolumn{3}{c}{ Associated pairs } \\
\cline { 2 - 4 } Selection régime & $\begin{array}{c}\text { Total/ } \\
\text { Anterior }\end{array}$ & $\begin{array}{c}\text { Total } \\
\text { Posterior }\end{array}$ & $\begin{array}{l}\text { Anterior/ } \\
\text { Posterior }\end{array}$ \\
Total scutellar bristles & -0.41 & $0.96 * * *$ & -0.50 \\
Anterior bristles & -0.48 & $0.79 * * *$ & $-0.85 * * *$ \\
Posterior bristles & 0.09 & $0.93 * *$ & -0.01 \\
& $* * \mathrm{P}<0.01 ; * * * \mathrm{P}<0.001$. &
\end{tabular}

0.09. No change occurred in the anterior bristle component while a significant response $(0 \cdot 10)$ occurred with posteriors. In fact, the change in total scutellar bristle number was accounted for almost solely by the change in the posterior bristles $(r=0.96$, table 5$)$.

\section{(ii) Posterior bristle selection}

Selection for divergence of posterior bristles (fig. 3c) alone led to a response pattern which paralleled that of selection for total bristle number. The coefficient of regression for posteriors here was 0.09 compared with 0.1 when selection was for total bristles and for total bristles the response was 0.12 compared with 0.09 when selection was directly on total bristles. Both total bristle and posterior bristle divergences are highly correlated $(r=0.93$, table 5$)$. There was no change or any significant association involving the anterior bristles.

\section{(iii) Anterior bristle selection}

Selection applied directly to anterior bristles (fig. $3 b$ ) eventually led to a significant response of $0 \cdot 13$. However, correlated with this positive change was a significant negative regression of -0.13 (table 4) for posterior bristles and a slightly negative though nonsignificant change in total bristle number. There was a direct negative correlated effect of -0.85 (table 5) of changes in anteriors upon changes in posterior bristles and in addition the negative change in total bristle number reflected negative change in posteriors $(r=0 \cdot 79)$. It can be seen from tables 2 and 4 that there was a negative correlated response of posterior bristles in both the high and low anterior bristle selection lines. It would seem that in the $60 \mathrm{D} 3 / 4$ population anterior and posterior bristles have a limited interrelationship. Direct selection for 

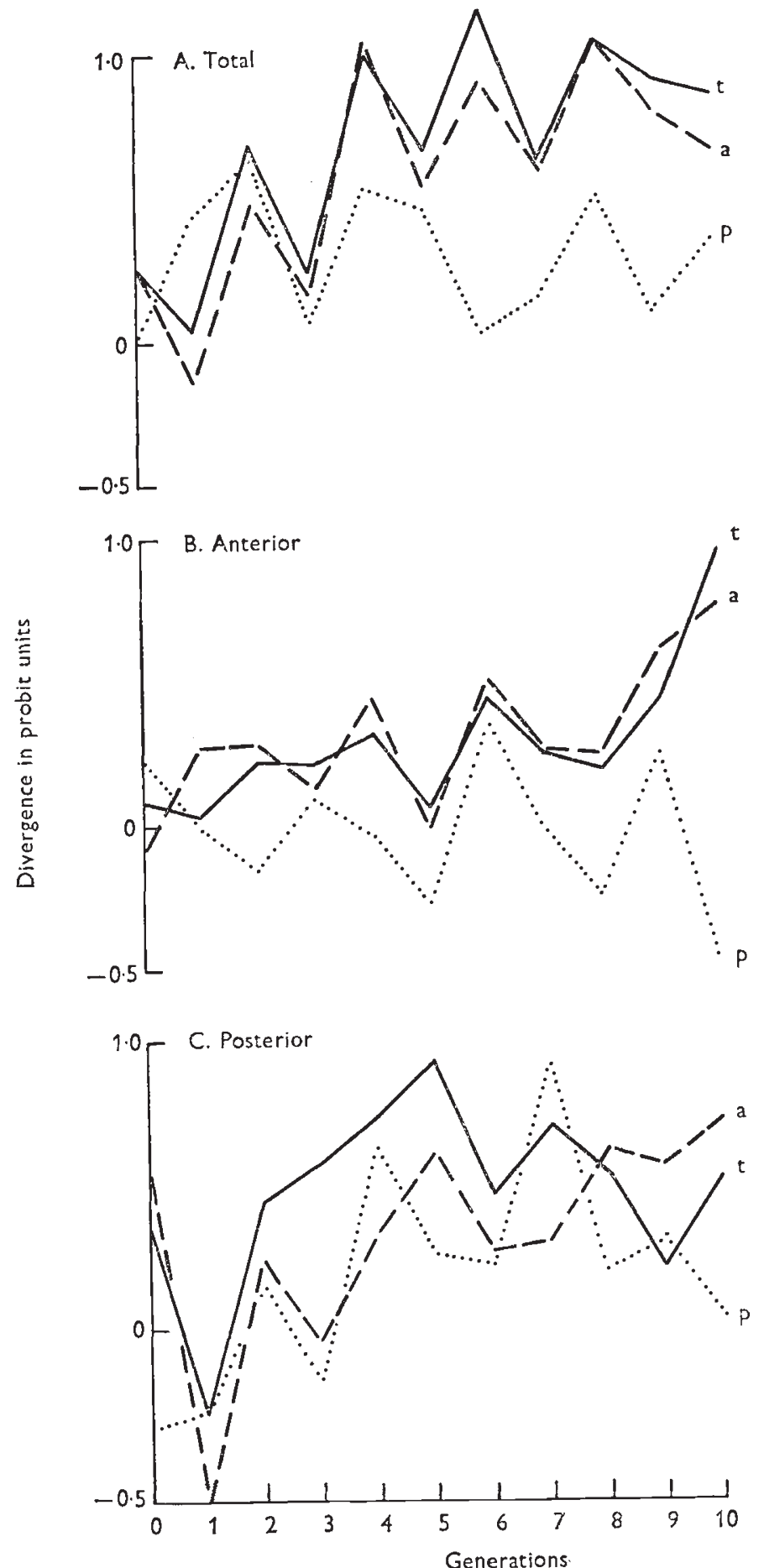

FIG. 4.-The divergence of total scutellar bristle number $(t)$ ( - ), anterior bristles (a) $(\cdots)$ and posterior bristles $(p)(\cdots)$ in probit units resulting from selection for directional changes in $\mathrm{A}$, total bristle number; $\mathrm{B}$, anterior bristles; and $\mathrm{C}$, posterior bristles for the $60 \mathrm{D} 4 / 5$ population. 
change in anteriors led to a correlated negative response in posteriors (fig. $3 b$ ). In contrast, where direct selection was upon posteriors there did not appear to be any change in anterior bristles (fig. $3 c$ ).

TABLE 6

Regression coefficients for the response of total, anterior, and posterior bristle numbers under diverging selection régimes for total bristles, anterior or posterior bristles respectively in the $60 D 4 / 5$ population

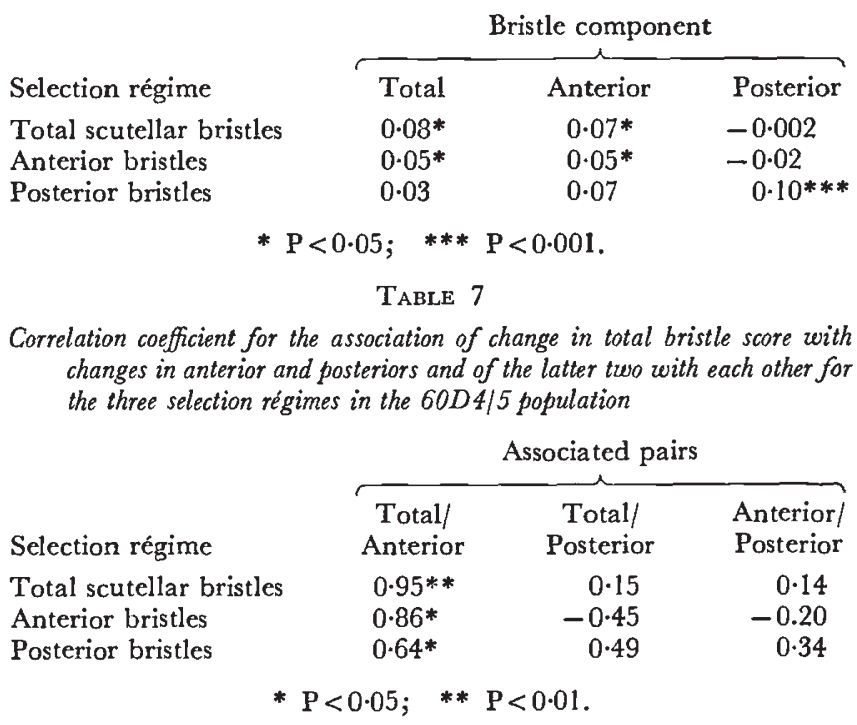

(B) 60D4/5 population

The response patterns for selection in this set of lines was not as dramatic as those for the $60 \mathrm{D} 3 / 4$ population and this is probably due to the fact that this set of lines was only carried for 10 generations. Nevertheless, there are significant conclusions.

\section{(i) Total bristle selection}

There was a significant response in total bristle number (fig. $4 a$ ) which was due largely to positive changes in anteriors (table 6). The strong association between total and anterior bristles was reflected in the regression coefficients of 0.08 and 0.07 respectively and by the almost perfect correlation $(r=0.95)$ between them. The lack of regression of posterior bristles on generations and of the absence of correlation of posteriors with either total or anterior bristles indicated that selection for total bristle number acted solely on the anterior bristle components.

\section{(ii) Anterior bristle selection}

The pattern of bristle changes (fig. $4 b$ ) here almost exactly paralleled the changes that occurred when selection was for total bristle number. There was a significantly positive response to diverging selection (fig. $4 b$, table 6) for both anterior (slope $=0.05$ ) and total bristles (slope $=0.05$ ) and a high correlation of 0.86 (table 7) between the two. There was no significant change in posterior bristles and neither was there a significant correlation of change in posteriors with either total or anterior bristle number changes. 


\section{(iii) Posterior bristle selection}

The response pattern in this case (fig. $4 c$ ) is the least clear of all due largely to the inordinately greater degree of variation from generation to generation (fig. 4c). There was, however, a significant regression of $0 \cdot 10$ (table 6) in the response of posterior bristles to diverging selection. This led to positive but non-significant changes in anterior and total bristle number. Despite these trends, and because of the generation to generation variation, there was no significant correlation of posterior bristles with changes in total or anterior bristles. The close association of total bristle number with anterior bristles in this population is reflected in the significant correlation of 0.64 (table 7 ).

\section{Discussion}

The principal conclusion of this study is that the $3 / 4$ and $4 / 5$ bristle thresholds which specify the canalisation zone for scutellar bristle number in Drosophila melanogaster are quite differently determined. Change in scutellar bristle number about the $3 / 4$ threshold as a result of selection is predominantly a function of changes in bristle number at the posterior sites. The specification of the $4 / 5$ threshold, however, is almost wholly determined by events at the anterior bristle sites. The high genetic correlations are quantified in table 8 , where it can be seen that in the population straddling the $3 / 4$ threshold, 92 per cent. of the change in posterior bristles is directly due to changes in total bristle number and conversely the coefficient of determination is 86 per cent. No change was observed in anterior bristle number in either case. In the population which straddles the $4 / 5$ threshold (60D4/5) 90 per cent. of the change in anterior bristle number is a direct function of selection for change in total bristle number and conversely 74 per cent. Analogously no change was observed in posterior bristle number.

TABLE 8

Coefficient of determination for the correlated responses to selection in the $60 D 3 / 4$ and $60 D 4 / 5$ populations

$\begin{array}{cllc}\text { Population } & \begin{array}{l}\text { Selected } \\ \text { character }\end{array} & \begin{array}{l}\text { Correlated } \\ \text { character }\end{array} & \begin{array}{c}\text { Coefficient } \\ \text { of } \\ \text { determination }\end{array} \\ 60 \mathrm{D} 3 / 4 & \text { Total } & \begin{array}{l}\text { Posterior } \\ \text { Total }\end{array} & 92 \% \\ & \text { Posterior } & 86 \% \\ 60 \mathrm{D} 4 / 5 & \text { Total } & \text { Anterior } & 90 \% \\ & \text { Anterior } & \text { Total } & 74 \%\end{array}$

This direct approach confirms the empirically based findings of Scowcroft et al. (1968) and Latter and Scowcroft (1970). In the former paper variation about the $3 / 4$ and $4 / 5$ thresholds was generated by manipulating dosage of alleles at the scute locus and in the latter by the use of inbreds, $F_{2}$ 's and limited selection for anterior bristles. In both of these papers it was determined that the specification of the $3 / 4$ bristle threshold on the underlying scale for total scutellars was primarily a function of the $1 / 2$ threshold for posterior bristles, while the $4 / 5$ threshold depended almost exclusively on the relative position of the $2 / 3$ threshold for anteriors.

These confirmatory sets of data emphasise the necessity for defining the elements of a developmentally controlled system. The principal model 
proposed to account for the canalisation of scutellar bristles is that of Rendel (1959, 1962, 1967). This model assumed that a population of individuals has an observed mean which is a continuous function of a single developmental variable called "make" which is defined as "that which develops or tends to develop a phenotype" (Rendel, 1967). Deviation from the canalised number of 4 occurs when the level of make falls outside a range of values bounded by two delimiting thresholds. In establishing the relationship between genotype and phenotype for a canalised system Rendel has made extensive use of the probit transformation. Robertson (1965) has argued that this may lead to incorrect inferences about the nature of the canalisation zone if scutellar bristle development is not a sequential or cumulative process as was assumed by Rendel. Robertson raised the possibility that the probabilities of bristle formation at the anterior and posterior sites could be modified independently.

The results reported above provide definite evidence that anterior and posterior bristles can be genetically modified in an independent manner. Therefore it is erroneous to equate make with a morphogenetic substance having definable biological characteristics. Rendel (1967) emphasised the need to treat the concept of canalisation with caution by allowing that total make may have several elements. This study then is a first step towards providing an operational basis for canalisation.

There is further evidence supporting the genetic independence of anterior and posterior scutellar bristles. In describing a genotype which significantly reduced the probit width of the 4 bristle canalisation zone, Scowcroft and Latter (1971) were able to show that this was largely due to a reduction in the probit width of the one anterior bristle per site class with a lesser effect on the posterior bristles, i.e. the degree of canalisation of anterior bristles is more flexible than that of posteriors. The effect of changing environmental conditions further indicates an independence of the genetic systems controlling the appearance of extra bristles at the different scutellar sites. Pennycuick and Fraser (1964) found a strong negative coefficient for anterior bristles with increasing temperature, and though less strong for posteriors, the coefficient was positive. Similar temperature coefficients for the same bristle sites were also found by Gibson (1970).

It is not proposed that the above results provide an absolute alternative to the model proposed by Rendel for the canalisation of scutellar bristle number. The intent was to examine some of the important variables involved in the regulation of scutellar bristle number at the wild type number of 4 bristles. These variables, namely anterior and posterior scutellars, would be included within Rendel's abstracted variable, "make". It should also be recognised that the processes studied by Rendel involved a strong scute mutant, whereas this study involved not only weak scute mutants but also a genotype $(60 \mathrm{D} 4 / 5)$ that had significantly reduced canalisation at 4 . The relative independence of anterior and posterior bristles in this system may not be apparent in Rendel's system, particularly when the mutant, scute, has a strong preference for removing the posterior scutellars. Obviously some developmental processes will influence the whole scutellum while others will affect individual bristle sites or regions.

It must not be overlooked that there was a negative correlation between anteriors and posteriors in the 60D3/4 lines selected for increased anterior bristles (tables 4 and 5). This was the only case where the two components 
showed marked interdependence. In the contrasting 60D3/4 lines selected for posterior bristles, the anteriors behaved independently. This suggests an hierarchial control of scutellar bristle development at least at the $3 / 4$ threshold. The capacity to form anteriors is strictly controlled and can only be increased by a reallocation of resources for posterior bristle development at this level. In all the other cases studied the capacity to respond to independent selection for anteriors or posteriors is not so strictly controlled.

Using a somewhat different approach Fraser and co-workers (Miller and Fraser, 1968; Fraser et al., 1968; Fraser, 1968; Fraser, 1970) have developed a model for the control of scutellar bristle number which is also incompatible with the notion of a single developmental variable. Their model consists of two major loci each with a specific set of modifiers. The scute locus and its modifiers control bristle number below the norm of four, while the extravert locus and its modifiers determine the level of scutellar bristle expression above four. Unfortunately their published data do not permit an anterior/posterior analysis of the type done here but it is appealing to suggest that the scute locus specific modifiers control the number of bristles at the posterior site while the extravert locus specific modifiers determine anterior bristle number.

\section{REFERENCES}

CHILD, G. 1935. Phenogenetic studies on scute -1 of Drosophila melanogaster. I. The associations between the bristles and the effects of genetic modifiers and temperature. II. The temperature-effective period. Genetics, 20, I09-126, 127-155.

Dubinin, N. P. 1933. Step-allelomorphism in Drosophila melanogaster. 7. Genet., 27, 443-464. FRASER, A. S. 1968. Variation of scutellar bristles in Drosophila. XV. Systems of modifiers. Genetics, 57, 919-934.

FRASER, A. S. I970. Variation of scutellar bristles in Drosophila. XVI. Major and minor genes. Genetics, 65, 305-309.

FRASER, A. S., ERWAY, L., AND BRENTON, W. 1968. Variation of scutellar bristles in Drosophila. XIV. Effects of temperature and crowding. Aust. 7. biol. Sci., 21, 75-87.

FRASER, A. S., SCOWCROFT, W. R., NASSAR, R., ANGELES, H., AND BRAVO, G. I965. Variation of scutellar bristles in Drosophila. IV. Effects of selection. Aust. 7. biol. Sci., 18, 619-641,

GIBson, J. 1970. Effects of temperature on selection for scutellar bristles. Heredity, 25, 59I-607.

LAtTER, B. D. H. 1964. Selection for a threshold character in Drosophila. I. An analysis of the phenotypic variance on the underlying scale. Genet. Res., 5, 198-210.

LAtTER, B. D. H. 1970. Selection for a threshold character in Drosophila. III. Genetic control of variability in plateaued populations. Genet. Res., 15, 425-439.

LATTER, B. D. H., AND SCOWCROFT, W. R. I970. Regulation of anterior and posterior scutellar bristle number in Drosophila. Genetics, 66, 685-694.

LINDSLEY, D. L., AND GRELL, E. H. 1967. Genetic variations of Drosophila. Carnegie Inst. Wash. Publ. No. 627.

MILLER, D. H., AND FRASER, A. S. 1968. Variation of scutellar bristles in Drosophila. XIII. Effects of scute alleles. Aust. 7. biol. Sci., 21, 61-74.

PAYNE, F. 19I8. An experiment to test the nature of the variations on which selection acts. Indiana University Studies, 5, I-45.

PENNYCUICK, P. R., AND FRASER, A. I964. Variation of scutellar bristles in Drosophila. II. Effects of temperature. Aust. 7. biol. Sci., 7, 764-770.

RENDEL, J. M. I959. Canalisation of the scute phenotype of Drosophila. Evolution, 13, 425-439.

RENDEL, J. M. I962. The relationship between gene and phenotype. 7. Theoret. Biol., 2, 296-308.

RENDEL, J. M. 1965. Bristle pattern in scute stocks of Drosophila melanogaster. Amer. Nat., 99, 25-32.

Rendel, J. M. 1967. Canalisation and Gene Control. Logos Press, London. 
ROBERTSON, A. 1965. Variation in scutellar bristle number-an alternative hypothesis. Amer. Nat., 99, 19-23.

SCOWGROFT, w. R. 1966. Variation of scutellar bristles in Drosophila. IX. Chromosomal analysis of scutellar bristle selection lines. Genetics, 53, 389-402.

SCOWGROFT, W. R., GREEN, M. M., AND LATTER, B. D. H. 1968. Dosage at the scute locus, and canalisation of anterior and posterior scutellar bristles in Drosophila melanogaster. Genetics, $60,373-388$.

SCOWGROFT, W. R., AND LATTER, B. D. H. 1971. Decanalisation of scutellar bristle number in Drosophila. Genet. Res., 17, 95-101.

SISMANIDIs, A. 1942. Selection for an almost invariable character in Drosophila. F. Genet., 44, 204-215. 